\title{
Not All Finns Think Alike: Varying Views of Assessment in Finland
}

\author{
Ashleigh Franco ${ }^{1}$ \\ ${ }^{1}$ School of Education, Johns Hopkins University, Baltimore, Maryland, United States \\ Correspondence: Ashleigh Franco, Johns Hopkins University School of Education, 2800 N. Charles Street, \\ Baltimore, MD 21218, United States. E-mail: ashleigh.franco@jhu.edu
}

Received: August 26, 2019

doi:10.5539/ies.v13n1p1
Accepted: September 28, 2019 Online Published: December 17, 2019

URL: https://doi.org/10.5539/ies.v13n1p1

\begin{abstract}
Finnish students have been among the world's strongest performers on standardized assessments throughout the past decade. Consequently, educators and scholars are interested in how to explain such results. A common explanation, as seen on social media, is that Finnish educators do not regularly assess their students. This study explores educators' views on assessment practices in Finnish education. First, the literature on assessment practices in Finland is reviewed. Then, using narrative inquiry as a research method, Finnish educators' views on assessment practices are examined. The research participants were two professors, two novice teachers, and two pre-service teachers, all connected to the same prominent university-based primary teacher education program in Finland. The narratives of the six participants in connection with assessment in Finland's education system highlight the variance in opinions about international standardized assessments as well as assessment practices at the classroom and school levels. Further, participants' narratives reveal the influence students' socioeconomic status may have on teachers' assessment practices.
\end{abstract}

Keywords: classroom assessment, international standardized assessments, narrative inquiry, novice teachers, pre-service teachers

\section{Introduction}

\subsection{The Problem}

Despite some fluctuations in the past decade, Finnish students remain top performers on international standardized assessments, such as the Trends in International Mathematics and Science Study (TIMSS), the Progress in International Reading Literacy (PIRLS), and the Program for International Student Assessment (PISA) (Organisation for Economic Co-operation and Development [OECD], 2013; OECD, 2016). Consequently, interest in Finland's educational system has increased. Educators around the globe want to understand what assessment in Finland looks like and what role it plays in the country's performance (Henrickson, 2012; Kasanen, Snellman, \& Räty, 2003; Kupiainen, Hautamaki, \& Karjalainen, 2009).

\subsection{Importance of the Problem}

Media commenters have perpetuated certain stories about why Finnish education is successful, particularly in regards to assessment (Faridi, 2014; Hancock, 2011; Pflueger, 2013; Strauss, 2012; Taylor, 2012). For example, Taylor (2012) noted that Finnish students begin school at the age of seven, rarely have homework, are not assessed during the first six years of their education, and take exams infrequently after that. Strauss (2012) pointed out that the only standardized assessment Finnish students take is their college matriculation exam. Who has not read an article or seen a meme on social media that attempts to explain that students in Finland are performing well because they do not have standardized assessments? Absent research, of course, these are just oversimplified hypotheses. This study explored the views of six Finnish educators (two professors, two pre-service teachers, and two classroom teachers) regarding international standardized assessments and classroom assessment practices. The research participants shared insights that shed new light on the Finnish educational system and, specifically, how Finnish educators view student assessment.

\subsection{Relevant Scholarship}

As context for this study, literature on standardized international assessment practices is reviewed. The review includes scholarship on perceived pros and cons of standardized assessments and why standardized assessments tend to be a controversial subject. In the final section, the review includes literature specific to assessment practices 
in Finland.

\subsubsection{Standardized Assessments}

Standardized assessments are one-time summative assessments that cannot be used to summarize a student's ability or a school's functionality (Deretchin \& Craig, 2007). Standardized assessments are not the optimal format for assessing critical thinking or life skills because they may not capture the creativity, independent thought, and other skills of students (Stewart, 2012). International standardized assessments assess specific subjects, such as mathematics, literacy, and science, which represent only a narrow sphere of the overall curriculum. Further, by placing a focus on these three subjects, international standardized assessments decrease teachers' autonomy and increase teachers' stress (Mundy, 2008).

Some educators oppose the ranking of countries, which portrays an unethical list of winners and losers; they feel that these lists do not provide beneficial information (Kennedy, 2010). According to Craig and Ross (2008), "studies linking student achievement test scores to teacher behavior [create] the public perception that student test scores monitor school and teacher success" (p. 284). Additionally, an assessment that compares 28 million students from 65 countries, representing more than $80 \%$ of the world's economy, can be viewed as an apples-to-oranges comparison (OECD, 2013). Furthermore, since participation in these international student assessments is voluntary and not all countries take part, it is impossible to determine a true ranking for any country.

Regardless of their limitations, international assessments are one of the only measures by which to compare the academic performance of students around the world. Schleicher, one of the two founders of PISA, believes that "without data, you are just another person with an opinion" (Ripley, 2013, p. 18). International student assessments have begun to include "detailed layers of research" on topics ranging from student socioeconomic and ethnic/racial statuses to school expenditures and the quality of teaching and learning (Mundy, 2008, p. 193).

Scores from international standardized assessments are driving public policy debates and widely influencing educational policies (Mundy, 2008; Wilby, 2014). At the very least, such assessments "give educators and citizens important tools for making evidenced-based claims for change" (Mundy, 2008, p. 211). In fact, both TIMSS and PIRLS explain that their missions are to provide countries with the information they need to make informed decisions (PIRLS-Overview, n.d.). Schleicher argued the value of data from international standardized assessments for collaborating across borders, seeking long-term solutions, and adopting positive policies that other countries have in place (Schleicher, 2014; Wilby, 2014).

\subsubsection{International Standardized Assessment: PISA}

Schleicher, the chief advisor on OECD's PISA project, studied physics at the University of Hamburg. During the course of his studies, he met Postlethwaite, an education professor who had begun to give a voice to the scientific nature of education. Together, these two men from very diverse backgrounds became the masterminds behind the notion that critical thinking can be measured through standardized assessment. Schleicher and Postlethwaite worked together to create the world's first standardized reading assessment, the PISA (Ripley, 2013).

Since its inaugural administration in 2000, the PISA has become the "world's premier yardstick" when it comes to international student assessment (OECD, 2013). Every three years, individual countries work with PISA to strategically select fifteen-year-old students at the end of their secondary education to represent their participating country's population and undergo the literacy, mathematics, and science assessments (National Center for Education Statistics, n.d.). The 2012 PISA included roughly 510,000 students who represented 28 million students from 65 countries and more than $80 \%$ of the world's economy (OECD, 2013). In Finland, the sample for the 2012 PISA consisted of approximately 9,000 randomly selected students from 311 schools (Opetus-ja kulttuuriministeriö, 2013).

At each triennial assessment, one of the three subjects is the area of focus (National Center for Education Statistics, n.d.). For example, literacy was the focus of the first assessment cycle in 2000 and also the 2009 cycle; mathematics was the focus in 2003 and 2012; and science was the focus in 2006 and 2015. Each student has the opportunity to take the PISA in his/her primary language of instruction (Kelly et al., 2013).

The aim of the PISA is not to capture student mastery of curriculum content but to determine how well students are capable of thinking critically in order to solve real-world problems (Ripley, 2013; Stewart, 2012). Ripley (2013), who took the assessment herself, became as acquainted as any other student with PISA. Ripley observed that PISA differed from other standardized assessments she had taken, and she was quite surprised at how effectively it was able to assess critical thinking skills. The unique assessment design, which includes both multiple-choice and student-constructed open-ended responses, is what sets PISA apart from other standardized tests and ultimately enables a comparison among various countries of student critical thinking skills (OECD, 2013). 
Sample PISA questions range from asking students to design their own coins - instead of counting coins - to defending an opinion about an advertisement. Many of the scientific questions require students to apply concepts to real-life scenarios, like what happens to muscles during exercise and what foods are high in particular vitamins (Ripley, 2013). Further, students are provided with formulas to use during the mathematics portion of the assessment, as challenging mathematical equations do not need to be memorized in real life. Schleicher admitted the PISA does not measure everything and has room for improvement (Ripley, 2013). Yet, this assessment remains a better predictor of students' preparedness for life over schooling (Ripley, 2013).

While no one assessment is perfectly capable of predicting how well students will perform in school or life, the PISA provides useful information about students' critical thinking abilities. In the case of Finland, PISA data has demonstrated that Finnish students are not innately more intellectually gifted than students from other countries, but rather, they have honed their intellectual skills significantly. This highlights the fact that significant changes in student achievement can take place even within one generation, as shown by the Finnish people (Ripley, 2013).

\subsubsection{International Standardized Assessment: TIMSS and PIRLS}

The International Association for the Evaluation of Educational Achievement (IEA) is responsible for both TIMSS and PIRLS. PIRLS assesses students across the globe on their literacy skills in the fourth grade, and TIMSS assesses students globally on both mathematics and science in the fourth, eighth, and twelfth grades (Stewart, 2012). The International Study Center at Boston College oversees the administration of both TIMSS and PIRLS. Although both tests assess subjects that PISA also assesses, TIMSS and PIRLS differ from PISA in that the former assess mastery of the curriculum. Accordingly, the intended curriculum, implemented curriculum, and achieved curriculum play a crucial role in the TIMSS design (Brown, 2010).

Groups of students have taken TIMSS every four years since 1995. The 2011 TIMSS cycle included the participation of 55 countries' educational systems in the fourth grade and 56 countries' educational systems in the eighth grade (TIMSS 2011 Results, n.d.). The precursors to TIMSS, between 1967 and 1984, were the First International Mathematics Study (FIMS), the First International Science Study (FISS), the Second International Mathematics Study (SIMS), and the Second International Science Study (SISS).

The PIRLS is an international student assessment of reading literacy among fourth graders around the world. The IEA established PIRLS in 2006 and has conducted the assessment every five years since then. The 2011 administration included 325,000 students across participating countries and educational systems.

The PIRLS assessment requires students to read, comprehend, and interpret texts of up to 1,000 words (PIRLS-Overview, n.d.). Three-quarters of all participating countries have student averages above the center point, indicating that overall, students from all participating countries are performing well. Moreover, evidence suggests that countries in which students were low performing in the fourth grade made "substantial gains in reading achievement by the sixth grade" (PIRLS-Overview, n.d.).

\subsubsection{Assessment in Finland}

Finnish students take their first external standardized assessment upon the successful completion of upper secondary level coursework (Niemi, Toom, \& Kallioniemi, 2012; Sahlberg, 2011; Stewart, 2012). The University of Helsinki established this National Matriculation Examination in 1852 as an entrance exam (Sahlberg, 2011). Until 1852, students were not formally assessed and schools focused solely on teaching. As Sahlberg (2011) explained, "since there are no standardized high-stakes tests in Finland prior to the matriculation examination at the end of upper secondary education, [teachers] can focus on teaching and learning without the disturbance of frequent tests to be passed" (p. 67). Henrickson (2012) explained in a literature review how this college matriculation exam is high-stakes but is not the only determining factor in terms of university acceptance. Students who graduate from vocational schools take certification exams and, based on the results, attend certain universities. However, the percentage of students at universities who come from vocational schools compared to upper secondary schools is much smaller (Sahlberg, 2011).

Since 1998, the Ministry of Education has monitored Finnish students' academic performance from the second to the ninth grades through sample-based national tests (Niemi et al., 2012; Stewart, 2012). These assessments "are carried out using a sample-based methodology that includes about $10 \%$ of the age cohort (6th- and 9th-grade students, for example) [and] measure students' learning in reading, mathematics, science, and other subjects in 3or 4-year cycles" (Sahlberg, 2011, p. 67). Participation in such assessments is mandatory (Niemi et al., 2012).

Despite their widely acclaimed success, the Finns are not overly enthusiastic about their PISA results (Sahlberg, 2011). Educators in Finland tend to oppose standardized assessments for several reasons, including the belief that curriculum, teaching, and learning should inform teacher practice, rather than testing (Sahlberg, 2011). Finnish 
educators also opine that teachers and schools — not third parties — should be the experts on their students' growth:

Many teachers and school principals [in Finland] think that PISA measures only a narrow band of the spectrum of school learning. There are also Finns who see that PISA is promoting the transmission of educational policies and practices that are not transferrable. (Sahlberg, 2011, pp. 55-56)

In addition, many Finns believe that students should not be judged according to statistical indicators and that standardized "testing would only cause harm and undue pressure on children as children need to build their confidence during these early years" (Brueggeman, 2008, p. 4). In fact, Sahlberg (2011) advocated for the inclusion of other skills on international assessments, such as learning-to-learn skills, social competencies, self-awareness, and creativity. Given this, it is not surprising that he stated, "[The Finns] are not much interested in PISA. It's not what we are about" (Hancock, 2011, p. 3).

The skepticism of Finnish people regarding international student assessments is understandable, since these assessments test only a narrow spectrum of the overall curriculum. However, this does not mean that Finns are opposed to all testing. In fact, they are proponents of holistic assessments and assessments that can "develop education at all levels of the system" (Niemi et al., 2012, p. 70). In general, assessments are connected to research for the purpose of development, but not to teacher performance. Sahlberg explained, "Accountability is something that is left when responsibility has been subtracted" (Partanen, 2011, para. 17). In other words, assessments are not administered solely to hold teachers accountable for student achievement. Assessments are also used in a formative sense to inform teachers of their students' progress (Niemi et al., 2012). This perspective on assessments promotes a relaxed learning environment that can, in turn, positively impact student performance (Sahlberg, 2011).

Finnish teachers are generally viewed as experts in their fields; therefore, they play a significant role in curriculum development, instruction, and student assessment (Sahlberg, 2011). The most common types of assessments found in Finnish classrooms are formative: teachers frequently design and implement their own assessments to monitor their students' progress (Kasanen et al., 2003; Niemi et al., 2012). These formative assessments are an integral aspect of daily life in comprehensive schools (Kasanen et al., 2003; Niemi et al., 2012). Teachers introduce them early and often throughout the school year (Kasanen et al., 2003). However, teachers avoid "presenting the situations as tests" and "students see the test situations as learning experiences rather than summative assessments" (Hendrickson, 2012, p. 36). While many of the assessments that teachers develop for students from primary to upper secondary school assess students' writing and critical thinking skills (Pöllänen, 2012), Finnish teachers focus on teaching and not on getting their students to pass these assessments (Hendrickson, 2012; Kasanen et al., 2003; Sahlberg, 2011).

Finnish educators conduct summative assessments less frequently. Typically, these assessments are used to gauge how well students meet the objectives of the national curriculum and are administered at the end of each school year (Niemi et al., 2012). Annual or semester-based report cards are the primary way Finnish educators formally communicate with parents regarding academic and behavioral progress (Niemi et al., 2012; Sahlberg, 2011). In upper secondary schools, teachers assess students at the end of each six- or seven-week period, accounting for a total of five or six assessments annually (Sahlberg, 2011). Although discrepancies will undoubtedly occur in teacher-created assessments, the Finns still believe this approach to be far more effective than standardized assessments (Stewart, 2012).

In summary, educators use both formative and summative classroom assessments in Finland. The only standardized assessment is the college matriculation examination. Finnish educators are concerned with how their students perform on international standardized assessments. Although information about assessment in Finland comes from reports (Kupiainen et al., 2009; Sahlberg, 2011) and previous research studies, such as Kasanen et al. (2003) who utilized ethnography to examine what one suburban teacher did in her primary classroom, no researchers have explored the insights of professors, pre-service teachers, and novice teachers regarding assessment in a single study. There are also no narrative inquiries on this topic. Hence, the research question for this study: What are Finnish educators' views on student assessment?

\section{Research Methods}

This article focuses on one research question that was part of a larger dissertation study on teacher training in Finland, which analyzed perceptions of research-based approaches, teacher quality, and moral matters. This study utilized narrative inquiry as a means to better understand teacher training in Finland, and specifically for the focus of this paper, views of teachers and teacher-trainees on assessment in education.

\subsection{Research Design: Narrative Inquiry}

The lives of individuals are comprised of experiences that they live, tell, relive, and retell (Clandinin \& Connelly, 
2000; Connelly \& Clandinin, 1990). Through narrative inquiry, researchers seek to understand and make sense of these experiences. By telling and retelling their stories, individuals shape their own lives and create and reconstruct personal meaning (Connelly \& Clandinin, 1990). Narrative researchers enter this meaning-making process and collaborate with participants over time (Clandinin \& Connelly, 2000). Narrative researchers focus on participants' personal experiences, with the goal of viewing the world from the participants' perspectives (Clandinin \& Connelly, 2000). Consequently, there are no predetermined outcomes in narrative inquiry (Syrjälä \& Estola, 2013).

This study's framework is based largely on Dewey's beliefs about situation, continuity, and interaction, which Connelly and Clandinin (2000) referred to as place, temporality, and sociality, respectively. Anchored by these beliefs, narrative researchers enter a metaphorical three-dimensional space to "[bind] the phenomenon, shape what passes for evidence, and determine what makes defensible research texts" (Clandinin \& Connelly, 2000, p. 49). Narrative researchers move inward and outward, backward and forward, within this metaphorical three-dimensional space. In the specific case of this study, the place is the selected university and its neighboring urban area. The temporality involves the past, present, and future of the participants' lives and the university's department of teacher education. Participants' internal conditions and relationships among participants and the researcher form the sociality.

\subsection{Participants and Sampling Procedures}

In order to identify participants who were familiar with assessment in the Finnish educational system, the researcher used both purposive and convenience sampling. After the Institutional Review Board (IRB) approved the study in May 2014, the head of the teacher education department at one of Finland's eight universities provided the researcher with names of colleagues and students who she thought might be interested in participating in this study. She also agreed to participate herself.

A small, purposive sample was appropriate for this study because the researcher sought in-depth narratives from a variety of viewpoints: professors, first year teachers, and pre-service teachers. Two individuals from each role participated. All participants were Caucasian and Finnish citizens. Five participants were female and one was male, a female to male ratio (83\%) that mirrored that of teachers in primary schools in Finland (79\%) in 2015 (The World Bank, 2018). To preserve confidentiality, pseudonyms were used: Kerttu and Aino for the professors; Milla and Minea for the novice teachers; and Arttu and Aada for the pre-service teachers.

\subsection{Data Collection}

The researcher gathered the participants' stories of their experience, following the guidelines of narrative inquiry (Connelly \& Clandinin, 1990). Between the fall of 2014 and the spring of 2015, participants and the researcher engaged in one-on-one email exchanges. During a 2.5-week trip to Finland in February 2015, the researcher conducted focus group and one-on-one interviews with participants, and shadowed participants for a minimum of a half-day each. Individual interviews generally took place after each shadowing experience and lasted between 30-60 minutes. Overall, the researcher spent five days in local Finnish schools and four days on campus at the university.

For all questions to participants, whether through email, during observations, or during the one-on-one and focus group interviews, the researcher followed a list of guiding questions. The questions focused on the university's primary teacher education program, and participants' views on assessment, research-based approaches, and teacher quality. All communication between researcher and participants was in English, although the majority of instruction the researcher observed at both the primary and university levels was in Finnish. Each participant, and others in the classroom at the time of each observation, offered to translate.

\subsection{Data Analysis}

Upon returning from Finland, the researcher transcribed the individual and focus group interviews and drafted participants' narratives. Each participant completed a member check by reviewing the part of the narrative that concerned him or her. Participants either confirmed the narrative accurately portrayed what they intended to convey or suggested changes. A couple of participants did suggest changes, but they were minor (e.g., despite using the expression in person, Aada was concerned the phrase that she lived "so close to the Russian border that she could walk there" was misleading).

Once member checks were completed, the researcher identified themes across the six narratives. The narratives shared certain commonalities: for example, each participant grew up in Finland, was a product of Finnish schools, and studied or worked at the same university. However, each narrative was also naturally unique. One way to visualize this web of connections among narratives is with a story constellation. When these stories are 
"juxtaposed with one another, they open up the inquiry spaces in human experience studies and lead to the creation of robust story constellations that capture unique combinations of narratives lived and told at particular junctures in time" (Craig, 2007, p. 177). In the story constellation shown in Figure 1, each circle represents a community, and each star represents an individual educator and his or her narrative. The commonalities became the threads that held the story constellation together, while the differences between narratives provided unique angles for understanding education in Finland.
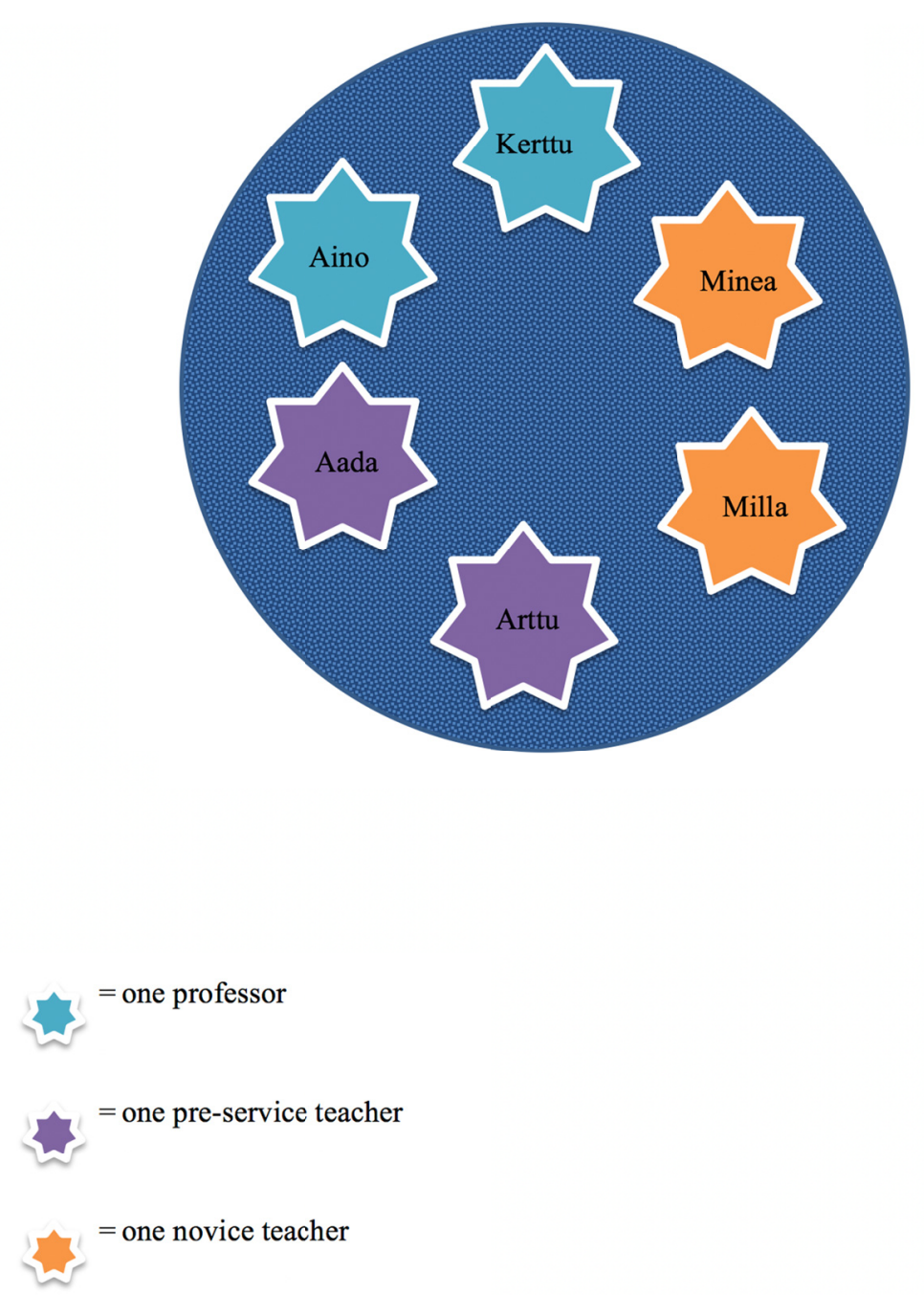

Figure 1 . The story constellation of this narrative inquiry

\section{Results}

Through their narratives over time, the participants in this study revealed insights that complicate the story of student assessment in Finland - both standardized assessment and classroom-based assessment. During the focus group with all six participants, participants paused awkwardly when asked about standardized assessments. Minea responded, "I don't follow [international assessments] but I know and have read about PISA and I'm not that concerned about it in my daily job." Later in the visit, however, it became clear that some Finnish educators were keenly aware of their international standing. Kerttu pointed out, for example, that her English comes in handy for the many international visitors the university receives. While international standardized assessments may not impact the daily lives of the Finnish teachers in this study, the assessments do have some impact on the daily lives of the professors at the university, as they often have visitors from around the world. 
Some educators in Finland oppose standardized assessments in the belief that the curriculum, teaching, and learning — not testing — should inform teacher practice. Minea exemplified this, as she emphasized that she could learn nothing from testing students that she could not learn from observing her students in the classroom. She shared:

I don't think there isn't anything that I could have learned in another way from the kids like how they are reading. I have to just listen to them read or how they are learning mathematics after I watch them do mathematics. I don't see why I should have to test them.

While she did not regularly assess her students, Minea did point out that she did pursue assessment of those students who struggled to keep up with the curriculum. These assessments were formative in nature and often completed by a special education teacher. Minea expressed the opinion that how often teachers assess might be linked to confidence in their own teaching abilities.

On the other hand, some teachers in Finland-including Milla and the teachers Aino's older son had in primary school-saw the advantages of assessing students. The parents of Milla's students-located in an upper middle-class neighborhood of Espoo- have noticed she is a younger teacher and like to see evidence of how their children are performing. Milla assessed her students on a monthly basis not only to appease parents, but also to inform her instruction.

I see every day that this [student] is doing poorly. He can't do these things but the parents don't believe you. They need to see every single paper-especially because I'm a younger teacher. I look younger than I am so they are always questioning my ability to teach so I have to have that pile of papers that show if students don't try, or if they are doing well or not so well.

A friend and colleague of Milla's, who taught foreign languages, admitted during a break in the teacher's lounge that she felt pressure to teach to the test. She explained that this pressure was not about getting her students to pass a test. Rather, she grappled with the concept of whether or not it was fair to assess students on something they have not been taught. During the same break at Milla's school, Milla had asked her principal on the researcher's behalf if he knew how many students were reading at or above grade level at the moment. He was unable to give a number or percentage, but did explain that only the students who were not doing well were assessed. Students in Espoo are tested on reading in second and fourth grade, and tested on mathematics and English in sixth grade, indicating that some forms of standardized assessment are part of the Finnish system. However, only the students who did not perform well on those assessments received additional monitoring.

Despite opposing testing in the primary grades, Aino used assessment in her university classroom. It was apparent during observation that university students were eager to check their assessment grades, which Aino had posted on the wall. Aino insisted that, because she used students' university identification numbers, they would not be able to tell who received what grade. She also shared that this practice allowed the pre-service teachers to see their performance in relation to their peers.

When asked what she hoped for Finnish education in coming years, Kerttu stated her wish that Finland continued not to have standardized assessments. She shared, "That's something that is kind of pushing to us and we are trying to reject it." When asked how Finland's increasing immigrant population would affect international assessment results, she was reluctant to answer and explained she could not predict that.

Among the many reasons why Finns are resistant to standardized testing, the one the study's participants expressed most prominently was that testing does more harm than good, especially for the primary students. Aada shared during the focus group that, "Well it's more important that children are feeling good and are healthy. Besides, [the PISA] just tests a piece of what the children are." Minea watched how her students performed in class to assess how they were developing. Her students also had a lot of freedom to be themselves in their classroom. Students could talk and move about as they wished; they often chose activities to their liking; and only at-risk students were assessed. Milla, for another example, vocalized her beliefs about the importance of teaching a wide variety of subjects in order to create well-rounded children. And, unfortunately, Aino experienced firsthand how testing caused undue harm to her older son.

Notably, participants' perceptions of international assessments did not correlate with their opinions about classroom assessments. Minea was vocal about the fact that she does not assess students; she knew how students were progressing based upon their work within the class. However, she did later admit that her school does use assessments, particularly for students not progressing as well as they are expected to. Milla's counter narrative is critical here, too, as it is the opposite of what educators around the world expect because of how media have portrayed assessment in Finland. 
Finally, the participants shared the considerable autonomy they had when it came to assessment in their classrooms. While the national core curriculum provided general guidelines, teachers freely choose their teaching and assessment methods. Minea, Milla, and Aada exemplified this during observation periods in their respective classrooms, where they delivered content in unique, in-depth ways. For example, Minea used a mix of whole group, small group, and one-on-one teaching strategies. Students in her class, as well as in Milla's and Aada's, were never rushed to finish their work. Students in all three classrooms had on-going projects they worked on a little each day at their own pace. The autonomy these teachers had over curriculum and assessment illuminated and reflected their views on classroom assessment.

\section{Discussion}

In this study, the narratives of professors, novice teachers, and pre-service teachers who experienced Finland's educational system firsthand, as both students and educators, were examined. The participants shared insights that shed light on the Finnish educational system and, specifically, how Finnish educators perceive assessment. A common thread among participants' narratives was that international standardized assessments did not impact educators' daily lives. This is consistent with the literature that underscores how Finns are not overly enthusiastic about their PISA results (Sahlberg, 2011). However, while international standardized assessments may not have impacted how teachers or professors taught, university professors were keenly aware of their country's standing on such assessments. Because students' standings on these assessments drew international attention, some professors even had to give university tours to visitors from around the world.

Views about classroom assessments varied. Some participants utilized assessments at the classroom and school levels and some educators utilized assessments much more frequently than others. First year teachers Milla and Minea's narratives were perhaps the most indicative of this. Milla assessed her students regularly and kept the assessment data on hand for when parents asked questions. She explained that parents wanted to see how their children were doing because she was a young teacher and did not have the parents' trust. Minea was very vocal about not assessing students. She said she was able to grasp how all students were performing by watching their performance every day in the classroom. Minea and Aino both supported, in their comments, Brueggeman's (2008) view, that standardized "testing would only cause harm and undue pressure on children as children need to build their confidence during these early years" (p. 4).

Interestingly, Minea believed how much teachers assess is related to their confidence as a teacher. Individual contexts - including parental involvement - may also help explain the differences between Milla and Minea's varying views on assessment. Milla taught in a wealthier suburban neighborhood while Minea taught in a low-income, urban setting. Milla's students were predominantly white and native Finnish, while approximately $30 \%$ of Minea's students were minority. Participants' narratives highlight a potentially serious social and democratic issue, namely, that teachers' or schools' assessment practices may be tied to students' socioeconomic status.

Participants' narratives can also be considered from the perspective of quality teaching. According to Finnish researchers Parpala and Lindblom-Ylänne (2007), an alignment between teaching methods and assessment is an aspect of quality teaching. If an alignment between teaching and assessment is an aspect of quality teaching, then it is noteworthy that no participant in this study made any direct connections to such an alignment.

From this study, a range of different perspectives on assessment in Finland emerges. Although the sample size for this study was comparatively small, the participants' experiences and opinions varied significantly. Some of the ideas found on social media regarding assessment in Finland are accurate, such as the Finnish educators' indifference toward international standardized assessments and their idea that testing causes undue harm to children. Yet the ideas that Finnish educators do not assess their students and standardized assessments are non-existent are less than accurate.

Connected to the fact that Finnish educators have varying opinions and assessment practices is the role of the educators' school and personal contexts. Could the real reason Milla frequently assessed her students be connected to a lack of confidence, perhaps connected to her disability? During interviews and observations, she came across as a confident young woman. Is it possible her lack of confidence is connected to her students' parents constantly questioning her ability to teach? This is more plausible and also somewhat alarming, given the variance in the socioeconomic statuses of her school and Minea's school. At least when it comes to Milla's and Minea's students, the students from a higher socioeconomic area experienced more frequent testing.

This research is one step in the fertilization of ideas across international borders. While no educational system should be grafted onto another due to the complex cultural minutia, primary educators and university professors may want to consider adopting some of the practices shared by educators in this study. The findings also point to 
areas for inquiry in future research. Two significant issues that came to light through this study include: (a) the connection between how much teachers assess and their confidence in their own teaching abilities; and (b) to what degree do individual contexts - including parental involvement and racial and socioeconomic issues - help explain the differences in teachers' perceptions about assessment. Research with larger sample sizes would be helpful in exploring these issues more in depth. Finally, this study does not specifically explore the link between student assessment in Finland and the country's high performance on international standardized assessment, which would be a fruitful area for further study.

\section{References}

Brown, K. D. (2010). Comparative studies research. In C. A. Kridel (Ed.), Encyclopedia of curriculum studies (pp. 129-131). Thousand Oaks, CA: SAGE Publications.

Brueggeman, M. A. (2008). An outsider's view of beginning literacy in Finland: Assumptions, lessons learned, and sisu. Literacy Research and Instruction, 47(1), 1-8. https://doi.org/10.1080/19388070701749371

Clandinin, D. J., \& Connelly, F. M. (2000). Narrative inquiry: Experience and story in qualitative research. San Francisco, CA: Jossey-Bass.

Connelly, F. M., \& Clandinin, D. J. (1990). Stories of experience and narrative inquiry. Educational Researcher, 19(5), 2-14. https://doi.org/10.2307/1176100

Craig, C. (2007). Story constellations: A narrative approach to contextualizing teachers' knowledge of school reform. Teaching and Teacher Education, 23(2), 173-188. https://doi.org/10.1016/j.tate.2006.04.014

Craig, C., \& Ross, V. (2008). Cultivating the image of teachers as curriculum makers. In F. M. Connelly (Ed.), The SAGE handbook of curriculum and instruction (pp. 282-305). Thousand Oaks, CA: SAGE Publications. https://doi.org/10.4135/9781412976572.n14

Deretchin, L. F., \& Craig, C. J. (2007). International research on the impact of accountability systems. Lanham, MD: Rowman \& Littlefield Education.

Faridi, S. (2014, June 24). Happy teaching, happy learning: 13 secrets to Finland's success. Education Week Teacher. Retrieved from http://www.edweek.org/tm/articles/2014/06/24/ctq_faridi_finland.html

Hancock, L. (2011, September). Why are Finland's schools successful? Smithsonian Magazine. Retrieved from http://www.smithsonianmag.com/innovation/why-are-finlands-schools-successful-49859555/?no-ist

Henrickson, K. (2012). Assessment in Finland: A scholarly reflection on one country's use of formative, summative, and evaluative practices. Mid-Western Educational Researcher, 25(1/2), 33-43. Retrieved from https://www.mwera.org

Kasanen, K., Snellman, L., \& Räty, H. (2003). Learning the class test. European Journal of Psychology of Education, 18(1), 43-58. https://doi.org/10.1007/bf03173603

Kelly, D., Xie, H., Nord, C. W., Jenkins, F., Ying Chan, J., \& Kastberg, D. (2013). Performance of U.S. 15-year-old students in mathematics, science, and reading literacy in an international context: First look at PISA 2012 (pp. 1-23). Washington, DC: NCES, IES, U.S. Department of Education. Retrieved from http://nces.ed.gov/pubs2014/2014024rev.pdf

Kennedy, K. J. (2010). Transnational research. In C. A. Kridel (Ed.), Encyclopedia of curriculum studies (pp. 899-902). Thousand Oaks, CA: SAGE Publications.

Kupiainen, S., Hautamaki, J., \& Karjalainen, T. (2009). The Finnish education system and PISA. Finland: Ministry of Education Publications.

Mundy, K. E. (2008). Comparative and international education: Issues for teachers. Toronto, Canada: Canadian Scholars' Press.

National Center for Education Statistics. (n.d.) Program for International Student Assessment (PISA)-Frequently asked questions. Retrieved from https://nces.ed.gov/surveys/pisa/faq.asp\#4

National Center for Education Statistics. (n.d.). Program for International Student Assessment (PISA). Retrieved from https://nces.ed.gov/surveys/pisa/pisa2015/pisa2015highlights_2.asp

Niemi, H., Toom, A., \& Kallioniemi, A. (2012). Miracle of education: The principles and practices of teaching and learning in Finnish schools. Rotterdam, NL: Sense. https://doi.org/10.1007/978-94-6091-811-7

Opetus-ja kulttuuriministeriö. (2013, February 12). PISA 2012: Proficiency of Finnish youth declining. Retrieved from https://minedu.fi/en/article/-/asset_publisher/pisa-2012-finlandska-ungas-kunskapsniva-har-sjunkit 
Organisation for Economic Co-operation and Development [OECD]. (2013). PISA 2012 results in focus. Retrieved from https://www.oecd.org/pisa/keyfindings/pisa-2012-results-overview.pdf

Organisation for Economic Co-operation and Development [OECD]. (2016). PISA 2015 results in focus. Retrieved from https://www.oecd.org/pisa/pisa-2015-results-in-focus.pdf

Parpala, A., \& Lindblom-Ylänne, S. (2007). University teachers' conceptions of good teaching in the units of high-quality education. Studies in Educational Evaluation, 33(3-4), 355-370. https://doi.org/10.1016/j.stueduc.2007.07.009

Partanen, A. (2017, February 17). What Americans keep ignoring about Finland's school success. The Atlantic. Retrieved from https://www.theatlantic.com/national/archive/2011/12/what-americans-keep-ignoringabout-finlands-school-success/250564/

Pflueger, H. (2013, March 9). Facts and interesting stuff. Retrieved from https://www.pinterest.co.uk/pin/450782243922254422/

Pöllänen, I. (2012). Finland: Perhaps the world's best education system. Skipping Stones, 24(4), 20.

Progress in International Reading Literacy Study (PIRLS)-Overview. (n.d.). Retrieved from http://nces.ed.gov/surveys/pirls/

Ripley, A. (2013). The smartest kids in the world: And how they got that way. New York, NY: Simon \& Schuster.

Sahlberg, P. (2011). Finnish lessons: What can the world learn from educational change in Finland? New York, NY: Teachers College Press.

Schleicher, A. (2014, May 8). PISA programme not about short-term fixes. The Guardian. Retrieved from $\mathrm{http}: / /$ www.theguardian.com/education/2014/may/08/pisa-programme-short-term-fixes

Stewart, V. (2012). A world-class education: Learning from international models of excellence and innovation. Alexandria, VA: ASCD.

Strauss, V. (2012, May 24). Ravitch: What is NCTQ? (and why you should know). The Washington Post. Retrieved from https://www.washingtonpost.com/blogs/answer-sheet/post/ravitch-what-is-nctq-andwhy-you-should-know/2012/05/23/gJQAg7CrlU_blog.html?utm_term=.flb3bc62de30

Syrjälä, L., \& Estola, E. (2013). Narrative research: From the margins to being heard. In C. J. Craig, P. C. Meijer, \& J. Broeckmans (Eds.), From teacher thinking to teachers and teaching: The evolution of a research community: Vol. 19. Advances in research on teaching (pp. 157-174). Bingley, UK: Emerald Books. https://doi.org/10.1108/S1479-3687(2013)0000019011

Taylor, A. (2012, November 27). Why Finland's unorthodox education system is the best in the world. Business Insider. Retrieved from http://www.businessinsider.com/finlands-education-system-best-in-world-2012 -11 ?op=1

The World Bank. (2018). Primary education, teachers (\% female). Retrieved from https://data.worldbank.org/indicator/SE.PRM.TCHR.FE.ZS?locations=FI

Trends in International Mathematics and Science Study (TIMSS) - TIMSS 2011 Results. (n.d.). Retrieved from http://nces.ed.gov/timss/results11.asp

Wilby, P. (2014, May 6). Academics warn international school league tables are killing "joy of learning". Retrieved from http://www.theguardian.com/education/2014/may/06/academics-international-schoolleague-tables-killing-joy-of-learning

\section{Copyrights}

Copyright for this article is retained by the author(s), with first publication rights granted to the journal.

This is an open-access article distributed under the terms and conditions of the Creative Commons Attribution license (http://creativecommons.org/licenses/by/4.0/). 